\title{
Interseeding Camelina and Rye in Soybean with Varying Maturity Provides Soil Cover without Affecting Soybean Yield
}

\author{
Kory L. Johnson, Hans J. Kandel D, Dulan P. Samarappuli and Marisol T. Berti *iD \\ Department of Plant Sciences, North Dakota State University, Fargo, ND 58104, USA; \\ johnsonkory14@gmail.com (K.L.J.); Hans.Kandel@ndsu.edu (H.J.K.); Dulan.Samarappuli@ndsu.edu (D.P.S.) \\ * Correspondence: Marisol.Berti@ndsu.edu; Tel.: +1-701-231-6110
}

Citation: Johnson, K.L.; Kandel, H.J.; Samarappuli, D.P.; Berti, M.T. Interseeding Camelina and Rye in Soybean with Varying Maturity Provides Soil Cover without Affecting Soybean Yield. Agronomy 2021, 11, 353. https://doi.org/10.3390/ agronomy11020353

Academic Editor: Umberto Anastasi and Aurelio Scavo

Received: 24 January 2021

Accepted: 13 February 2021

Published: 16 February 2021

Publisher's Note: MDPI stays neutral with regard to jurisdictional claims in published maps and institutional affiliations.

Copyright: (c) 2021 by the authors. Licensee MDPI, Basel, Switzerland. This article is an open access article distributed under the terms and conditions of the Creative Commons Attribution (CC BY) license (https:// creativecommons.org/licenses/by/ $4.0 /)$

\begin{abstract}
Low adoption to utilize cover crops interseeded into soybean (Glycine max (L.) Merr.), in the northern Plains in the USA, is due to a short growing season and a few adapted winter-hardy species. The objective was to evaluate the impact of interseeded winter camelina (Camelina sativa (L.) Crantz) and winter rye (Secale cereale L.) using different soybean relative maturities on soybean yield, canopy coverage, spring cover crop biomass, and subsequent wheat (Triticum aestivum L.) yield. Cover crops interseeded into early-maturing (0.4-0.8) soybean cultivars had more fall coverage compared with the 0.9 maturity cultivar, but the spring biomass was similar for all maturities. The soybean yield of the 0.9 cultivar was significantly higher, $2365 \mathrm{~kg} \mathrm{ha}^{-1}$ compared with $2037 \mathrm{~kg} \mathrm{ha}^{-1}$ for the 0.4 cultivar. Rye outperformed winter camelina and had higher fall canopy cover (15 vs. $7 \%$ ), spring canopy cover (16\% vs. $4 \%$ ), and higher spring biomass (313 vs. $100 \mathrm{~kg} \mathrm{ha}^{-1}$ dry matter). Spring wheat, after rye, yielded $90 \%$ of the check. It is not recommended to plant spring wheat following winter rye, but there was no negative yield effect from winter camelina. Interseeding cover crops into soybean in the northern Plains is possible but needs further research to optimize interseeding systems.
\end{abstract}

Keywords: cover crop; canopy cover; wheat; winter survival

\section{Introduction}

Soil erosion is a major problem in soybean production regions as crop residue is limited [1], leaving the soil with limited cover during the winter. The Red River of the North Valley of North Dakota and Minnesota is flat and has few natural wind barriers. The importance in finding a solution to loss of topsoil due to erosion, especially following soybean production in conventionally tillage systems, is vital in sustaining soil health, as continued topsoil loss from wind and water erosion will have detrimental effects on crop productivity of regional soils and eventually will increase fertilizer inputs if current management practices continue [2].

Cover crops can provide protection to the soil by reducing soil particle removal due to wind and water erosion. Cover crops can be winter grasses, forbs, or legumes that are typically planted in the fall and overwinter until the spring. Cover crops are used for erosion control, improving soil structure, moisture, and nutrient content, increasing beneficial soil biota, suppressing weeds, providing habitat for beneficial predatory insects, facilitating crop pollinators, providing wildlife habitat, and as forage for farm animals [3]. Cover crops may provide benefits to the soil, the ecosystem, and potentially increase grain yield of the following crop by increasing diversity of microorganisms, providing soil coverage, enriching soil organic matter, and enhancing the nutrient cycling [4,5]. Diverse plant species promote the soil microbial community differently, and this may result in greater soil microbial diversity [6]. Soil organic matter is a major contributing factor in soil productivity and can be enhanced by incorporating cover crops [7].

Although cover crop utilization has increased in the Corn Belt and the northern Great Plains Region (North of latitude $44^{\circ}$, including eastern Montana, north-eastern Wyoming, most of North and South Dakota, and the Canadian Prairies), adoption has been slower 
than average for overwintering cover crops. This is primarily due to timing of when soil moisture is available for successful cover crop stand establishment at time of seeding late summer or early fall and shorter growing season to establish sufficient growth for overwintering for winter annuals. Overwintering cover crops are planted after or between the primary crop with the goals of surviving the winter and to resume growth in the spring. Cover crops must produce enough biomass in the fall and or spring for benefits to be expressed [8]. Following soybean harvest, there is an extremely short remaining growing period before a fall frost poses challenges for establishing a cover crop with conventional seeding methods. Alternative methods of planting are needed for successful biomass growth and soil coverage.

Most producers evaluate cropping systems based on the economics of grain yield and short-term profitability, not on the value of soil health and long-term sustainability. Several studies have suggested current conventional cropping systems are less sustainable because of limited benefits to the ecosystem [9-11].

Camelina (Camelina sativa (L.) Crantz) is a short-season annual oilseed crop in the Brassicaceae family with agronomic low-input features that has been produced for the oil in Europe for over 3000 years [12]. Camelina has two biotypes, summer and winter [13,14]. The winter annual biotype is winter-hardy and has a high level of tolerance to drought and lowtemperature stress, and has the ability to adapt across a wide range of environments $[14,15]$. Because of winter camelina's desirable agronomic traits, further research is being conducted to improve its adoption of cultivation and cover crops use.

North Dakota farmers need winter annual biotypes of camelina that are proven to be winter-hardy and suitable for the northern Plains Region [13,16]. Fall-seeded camelina will remain in the rosette stage throughout the winter, with growth resuming in the spring [17].

Rye is the most common and reliable winter annual cover crop utilized in the upper Midwest (Iowa, Michigan, Minnesota, North Dakota, South Dakota, and Wisconsin). It is one of the few cover crops that can establish successfully when planted late in the growing season. It is winter-hardy throughout the region and accumulates biomass before spring planting of the subsequent crop [18-20]. Rye has an extensive root system that can lead to reduction of nitrate leaching [21]. Rye can germinate at temperatures as low as $1{ }^{\circ} \mathrm{C}$ and vegetative growth can begin at $3^{\circ} \mathrm{C}$ [22]. With vegetative growth still active at near freezing temperatures, winter rye has a longer time in the field compared with non-winter-hardy cover crops to produce biomass and canopy coverage, which is an important factor in North Dakota. With a prolonged growing season, winter rye can be a good weed suppressor in the fall and in the spring when soil canopy coverage increases rapidly [23].

Several researchers have reported on interseeding cover crops into soybean at different stages of growth $[17,24,25]$. Interseeding involves planting of the cover crop by drilling the seed into the soil or broadcasting it before soybean matures. The advantages of interseeding include not needing to seed after soybean harvest (during the busy harvest season), providing more time for cover crop establishment, improved cover crop growth, and increased winter survival [26]. Interseeding usually requires special or modified equipment that is able to leave established soybean plants undamaged. Research has shown that weeds can be suppressed effectively without yield reduction of the main crop by interseeding cover crops in organic farming systems [27,28].

Berti et al. [17] reported that the camelina plants have difficulty competing with the dense canopy of soybean, and interseeding should occur during soybean reproductive stages $[17,25]$. Establishment of winter camelina and winter rye by aerial broadcasting is mainly dependent on timely rainfall after sowing [29] and seeding rates need to be increased by a minimum of $50 \%$ [22].

Winter rye as a cover crop can be integrated into existing corn (Zea mays L.)-soybean production systems and has been recommended as a cost-effective strategy for improving environmental stewardship [21]. Rye is superior among cool-season cereal cover crops for absorbing unused soil $\mathrm{NO}_{3}-\mathrm{N}$. It has a fast-growing fibrous root system, which helps scavenge for residual $\mathrm{NO}_{3}-\mathrm{N}$ throughout the soil profile. Where rye has been interseeded into soybean 
in August, leaching losses from September to May were less than $5.6 \mathrm{~kg}$ of N ha${ }^{-1}$ [30]. Rye has the ability to access $\mathrm{K}$ from lower in the soil profile [31].

Although several studies have been done on interseeded cover crops in soybean $[17,24,25,32,33]$, this research is unique as it is evaluating the effect of soybean maturity on the establishment of winter camelina and rye and the following hard red spring wheat (HRSW) (Triticum aestivum L.) crop. The objectives of this research were to evaluate cover crop development and biomass production when interseeded into soybean cultivars with different relative maturity and to evaluate the effect of cover crop growth on soybean and HRSW grain yield.

\section{Materials and Methods}

\subsection{Experimental Sites}

The experiments were established at North Dakota State University's (NDSU) experiment field $\left(46.932124^{\circ} \mathrm{N}, 96.858941^{\circ} \mathrm{W}\right)$ located near Fargo, ND, between 2016 and 2018. The soil at the experimental site is a mixture of Fargo (fine, smectitic, frigid Typic Epiaquerts) and Ryan (fine, smectitic, frigid Typic Natraquerts) silty clay, naturally poorly or very poorly drained and slowly permeable. The parent material of the soil is clayey glaciolacustrine deposits [34]. The crop grown before soybean seeding was corn in 2015 and HRSW in 2016. Conventional tillage management practices were used before the establishment of the experiment. No-till management was used for the first time at the research site in the spring of 2016 and has been continued during the subsequent seasons. Weather data for the 2016, 2017, and 2018 growing seasons were obtained from the North Dakota Agricultural Weather Network [35] at the Fargo weather station located in Fargo, ND.

\subsection{Experimental Design and Management}

Two cover crop experiments were conducted during each of the 2016 and 2017 growing seasons with data collection on spring wheat in 2017 and 2018. Each of the experiments were considered a separate environment. The method of establishment was not an objective in this trial. Therefore, in one experiment in each year, the cover crop was direct-planted. In the second experiment, simulated air seeding was used to represent possible cover crop establishment methods.

The experimental design was a randomized complete block with a factorial arrangement. There were four replicates per experiment and each replicate consisted of 20 experimental units. The experimental unit size was $1.52 \times 7.62 \mathrm{~m}$. Treatments included soybean relative maturity (cultivar), cover crop species, and cover crop seeding rate. Soybean relative maturities included $0.4,0.5,0.8$, and 0.9 . The 0.4 is the earliest maturing cultivar. Soybean cultivars are listed in Table 1. All soybean cultivars were glyphosate-tolerant (Roundup Ready 2 Yield), carried resistance to soybean cyst nematode (Heterodera glycines Ichinohe) (except AG0434), had Phytophthora resistance, and were pre-treated by the seed company (Asgrow; Bayer, Monheim, Germany) with Acceleron (a.i. pyraclostrobin and metalaxyl) seed treatment. Acceleron seed treatment is a fungicide combination providing protection from seed and soil borne diseases such as but not limited to; Pythium irregulare, Phytophthora sojae, Fusarium solani, and Rhizoctonia solani. The cultivars were inoculated with Vault SP (Bradyrhizobium japonicum) inoculum (BASF, Ludwigshafen, Germany) at a rate of $1.8 \mathrm{~g} \mathrm{~kg}^{-1}$ soybean seed on the day of planting to encourage nodulation. The same cultivars were used in both growing seasons.

Soybean was planted as soon as field conditions were favorable in early to mid-May, with four soybean rows spaced 30.5-cm apart and using a seeding rate of 469,300 live seeds ha ${ }^{-1}$. The plots were planted with a Hege 1000 no-till planter (Hege Company, Waldenberg, Germany). Seeds were planted to a depth of approximately $3 \mathrm{~cm}$. 
Table 1. Details of soybean cultivars used in experiments in 2016 and 2017 at Fargo, ND, USA.

\begin{tabular}{ccccccc}
\hline Cultivar & Company & Maturity & IDC ${ }^{\dagger}$ & SCN $\ddagger$ & Canopy & Plant Height \\
\hline AG0434 & Asgrow & 0.4 & 2.0 & None & Medium bushy & Medium \\
AG0536 & Asgrow & 0.5 & 1.6 & $\mathrm{R}$ & Medium bushy & Medium tall \\
AG0835 & Asgrow & 0.8 & 1.8 & $\mathrm{R}$ & Bushy & Medium tall \\
AG0934 & Asgrow & 0.9 & 2.1 & $\mathrm{R}$ & Medium bushy & Medium short \\
\hline
\end{tabular}

${ }^{\dagger}$ IDC $=$ iron deficiency chlorosis. IDC scored on $1-5$ scale $(1=$ Green, $3=$ Yellow, $5=$ Dead $)[36] ;$ SCN $=$ soybean cyst nematode. $\mathrm{R}=$ resistant $\mathrm{SCN}$ using PI347654 source.

Cover crop treatments were none (control), winter camelina, and rye. Cover crop seeding rate treatments were $100 \%$ of seeding rate and $75 \%$ of seeding rate. Winter camelina cultivar "Joelle" was planted at $6.72 \mathrm{~kg} \mathrm{ha}^{-1}$ live seeds for the $100 \%$ seeding rate treatments and $5.04 \mathrm{~kg} \mathrm{ha}^{-1}$ for $75 \%$ rate treatments to a depth of $1.3 \mathrm{~cm}$. The quantity of winter camelina seeds per $\mathrm{kg}$ can be upwards of 770,000 seeds $\mathrm{kg}^{-1}$ compared with 39,000 seeds $\mathrm{kg}^{-1}$ for rye [12]. The rye cultivar "Rymin" was planted at $67.2 \mathrm{~kg} \mathrm{ha}^{-1}$ for the $100 \%$ seeding rate and $50.4 \mathrm{~kg} \mathrm{ha}^{-1}$ for $75 \%$ rate, to the depth of $2.5 \mathrm{~cm}$. Germination testing was conducted before planting. For both 2016 and 2017 growing seasons, a 95\% germination rate was determined for rye and $90 \%$ for camelina. Seeding rate was adjusted based on germination.

All cover crops were interseeded into established soybean at the R7 growth stage of the 0.4 maturity cultivar. Staging of soybean was based on NDSU Soybean Production Field Guide, which defines R7 as beginning maturity-one normal pod on the main stem that has reached its mature pod color [37]. In one experiment, the cover crops were planted in a single furrow in the center of all soybean rows, $15.3-\mathrm{cm}$ from each corresponding row, resulting in three cover crop rows per experimental unit. Furrows were made to the depth of $1.3 \mathrm{~cm}$ for camelina and $2.5 \mathrm{~cm}$ for rye using a standard garden hoe. No furrows were made in the control plot (without cover crops). In the other experiment, the cover crop seed was broadcasted, to simulate seeding by airplane.

Weeds in soybean plots were controlled twice in 2016 and once in 2017, prior to the planting of the cover crops using (a.i. 48.7\% glyphosate, $\mathrm{N}$-(phosphonomethyl) glycine, in potassium salt form) Roundup PowerMAX (Monsanto Co., St. Louis, MO, USA) and (12.6\% (E)-2-[1-[[(3-chloro-2-propenyl)oxy]imino]propyl]-5-[2-(ethylthio)propyl]-3hydroxy-2-cyclohexen-1-one) and SelectMax (Valent U.S.A. Corporation, Walnut Creek, CA, USA). The herbicides were applied using TeeJet 8001 XR nozzle at a rate of 1.6 in $94 \mathrm{~L} \mathrm{ha}^{-1}$ water and a spray pressure of $200 \mathrm{kPa}$. Cover crops were terminated in the spring using Roundup WeatherMAX.

In 2017 and 2018, (a.i. 9.15\% S-cyano(3-phenoxyphenyl)methyl (+/-)-cis/trans-3-(2,2dichloethenyl)-2,2-dimethylcyclopropanecarboxylate) Mustang Maxx (FMC Corporation, Philadelphia, PA, USA) was applied at a rate of $1.75 \mathrm{~L} \mathrm{ha}^{-1}$ to both soybean and HRSW as soybean aphid (Aphis glycines Matsumura) levels in soybean and grasshopper (Orthoptera: Acrididae) thresholds in HRSW surpassed thresholds as described by NDSU [37,38]. Important field operation and measuring dates are provided in Table 2.

Wheat was planted after cover crops were terminated. Fertilizer was broadcast-applied during the spring before the HRSW at a rate $112 \mathrm{~kg}$ per ha ${ }^{-1}$ of $\mathrm{N}$ using urea (46-0-0). In both years, the HRSW cultivar "Glenn" was used. All HRSW plots were planted as soon as field conditions were favorable in early May, with a Great Plains 3P605NT no-till planter (Great Plains Ag, Salina, KS, USA). Experimental units had seven rows spaced 18.3-cm apart. The seeding rate was 2,739,000 live seeds ha ${ }^{-1}$ and seeding depth approximately $2 \mathrm{~cm}$. Weeds were controlled using Wolverine Advanced (4.56\% fenoxaprop-p-ethyl, $1.5 \%$ pyrasulfotole, $6.13 \%$ bromoxynil octanoate, $5.93 \%$ bromoxynil heptanoate) (Bayer CropScience LP, Research Triangle Park, NC, USA) to control selective postemergent grassy and broadleaf weeds. 
Table 2. Dates of important measurements and field operations between 2016 and 2018 at Fargo, ND, USA.

\begin{tabular}{ccc}
\hline Measurement/Operation & Date \\
\hline Soybean planting & 2016 & 2017 \\
\hline First herbicide application & 6 May & 6 May \\
Second herbicide application & 9 June & 9 June \\
Cover crop planting & 30 June & - \\
Cover crop Canopeo ${ }^{\dagger}$ reading & 22 Aug. & 22 Aug. \\
Soybean harvest & 15 Nov. & 31 Oct. \\
& 27 Sept. & 6 Oct. \\
\hline Spring cover crop Canopeo reading & 2017 & 2018 \\
Spring cover crop biomass & 1 May & 13 May \\
Cover crop termination & 1 May & 13 May \\
Wheat planting & 6 May & 16 May \\
Wheat Canopeo reading & 6 May & 16 May \\
Wheat harvest & 9 June & 9 June \\
\hline
\end{tabular}

${ }^{\dagger}$ Canopeo, a mobile application developed to measure crop canopy coverage.

\subsection{Evaluations}

Soybean plant density was determined shortly after emergence (VE) by randomly selecting one linear $\mathrm{m}$ near the center of the plot. Then, counting all plants within the linear $m$ in both inner two rows.

Cover crop canopy coverage, defined as a percentage of green plant matter, which covers the soil, was measured using the mobile phone application "Canopeo" developed by the Oklahoma State University Department of Plant and Soil Sciences, following cover crop emergence, before the first killing frost, and before termination in the spring. Canopeo measures the fractional green canopy cover through an image processed through the Canopeo application providing a green canopy coverage percentage [39]. Canopy coverage data was collected from pictures used taken in the center of each plot at a height of $1 \mathrm{~m}$, allowing $15 \mathrm{~cm}$ from the outside of last soybean row. Picture data were then processed using Canopeo application, which resulted in a percentage of green tissue within the area of the picture.

Cover crop biomass was collected in the spring preceding termination and subsequent HRSW planting. Biomass was sampled from an area within a $30.5 \times 50 \mathrm{~cm}$ plastic square $\left(0.1525 \mathrm{~m}^{2}\right)$. The square was randomly tossed into each half of the lengthwise portion of each experimental unit, creating two samples per plot. An average of the two samples was used for the biomass calculation. Biomass samples were created by cutting all cover crop plants within the square at the soil level. Samples were then place in a dryer at a temperature of $40^{\circ} \mathrm{C}$ until biomass sample showed no difference in weight during $24 \mathrm{~h}$. Samples were then individually placed on a tray where foreign material was removed before weighing the sample using a Mettler Toledo XS6001S scale (Mettler-Toledo, LLC, Columbus, $\mathrm{OH}, \mathrm{USA})$.

The soybean and HRSW plots were harvested, after physiological maturity [40,41], at harvestable moisture content using a Wintersteiger Classic plot combine (Wintersteiger Ag. Ried, Austria). Seed samples were cleaned using a Clipper seed cleaner (Ferrell-Ross, Bluffton, IN, USA), and seed samples were then weighed for yield. Moisture and test weight were determined using a GAC 2100 moisture tester (DICKEY-John Corp., Minneapolis, MN, USA), and observations were corrected to $13 \%$ and $13.5 \%$ moisture content for soybean and HRSW, respectively. Soybean oil and protein contents were not significantly different between treatments and are not reported in this paper. 


\subsection{Statistical Analysis}

Statistical analysis was conducted using a randomized complete block design with a two-factor factorial arrangement. All dependent variables were analyzed with a mixed model (PROC MIXED) on SAS 9.3 [42]. Cultivars and cover crops were considered fixed variables, and environment was considered a random variable. Cover crop treatments, winter camelina and cereal rye, and $100 \%$ and $75 \%$ seeding rate were combined across soybean cultivars during statistical analysis to make five treatments (Camelina100, Camelina75, Rye100, Rye75, and Check, without cover crops).

Homogeneity of variance tests was done to determine if environments (defined as the combination of location-year) could be combined. If homogeneous, a combined analysis across four environments was conducted. Treatment means were separated using Fisher's protected least significant difference (LSD) at the $95 \%$ level of confidence $(p \leq 0.05)$.

\section{Results and Discussion}

\subsection{Weather Data}

The production years 2016 and 2017 differed for total precipitation and air temperature as observed by NDAWN weather stations (Tables 3 and 4). During the 2016 interseeding of the cover crops, below average precipitation during seeding was followed by above average precipitation in September and October. Differences were also observed between growing seasons for spring data collection. The spring of 2017 had below average precipitation, yet with soil moisture levels greater than that of 2018 (due to lower precipitation during the 2017) (Table 3).

Table 3. Monthly total rainfall in 2016, 2017, and 2018 compared with the 30-year average at Fargo, ND, USA.

\begin{tabular}{ccccc}
\hline & & & Total Rainfall & \\
\hline Month & $\mathbf{2 0 1 6}$ & $\mathbf{2 0 1 7}$ & $\mathbf{2 0 1 8}$ & Historical Avg. ${ }^{+}$ \\
\hline & & & $\mathrm{mm}$ & 35 \\
April & 59 & 25 & 6 & 71 \\
May & 33 & 26 & 44 & 99 \\
June & 69 & 57 & 123 & 71 \\
July & 132 & 23 & 81 & 65 \\
August & 48 & 58 & 101 & 65 \\
September & 80 & 70 & 64 & 55 \\
October & 64 & 20 & 58 & 461 \\
Total & 485 & 279 & 477 & \\
\hline
\end{tabular}

${ }^{\dagger}$ Historical data represents a 30-year average from 1981-2010 [35].

The 2017 growing season only had $279 \mathrm{~mm}$ of precipitation compared with 485 and $477 \mathrm{~mm}$ for 2016 and 2018, respectively (Table 3). This difference was the leading factor in lower cover crop germination rates, irregular germination, and difficulties during the cover crop establishment phase. In addition, below average temperatures as compared with the historical average during the months of March and April of 2018 (Table 4) negatively affected the already inhibited cover crops, resulting in low biomass growth. Solar radiation was higher during the 2017-2018 cover crop growing season, compared with the 2016-2017 season.

\subsection{Cultivar and Cover Crops}

\subsubsection{Cultivar}

The analysis of variance and significance levels are provided in Table 5. On average soybean established plant density was 440,000 plants $^{-1} a^{-1}$ and not significantly different among cultivars. Interseeding cover crops into different cultivars at the R7 stage of the early maturity cultivar produced no soybean yield reductions comparing soybean yield with cover crops (camelina or rye) to the check plot of each cultivar, which is consistent with previous research $[17,24,25]$. 
Table 4. Monthly average air temperature and solar radiation for 2016, 2017, and 2018, and historical data for average air temperature at Fargo, ND, USA.

\begin{tabular}{cccccccc}
\hline & \multicolumn{3}{c}{ Average Air Temperature } & \multicolumn{3}{c}{ Average Solar Radiation ${ }^{\dagger}$} \\
\cline { 2 - 8 } Month & $\mathbf{2 0 1 6}$ & $\mathbf{2 0 1 7}$ & $\mathbf{2 0 1 8}$ & Historical $\ddagger$ & $\mathbf{2 0 1 6}$ & $\mathbf{2 0 1 7}$ & $\mathbf{2 0 1 8}$ \\
\hline & \multicolumn{3}{c}{${ }^{\circ} \mathrm{C}$} & & & Langley & \\
March & 3.3 & -1.5 & -3.0 & -2.3 & 280 & 308 & 325 \\
April & 6.3 & 7.6 & 1.7 & 6.8 & 337 & 417 & 479 \\
May & 15.5 & 14.0 & 18.0 & 14.0 & 509 & 465 & 500 \\
June & 20.0 & 19.8 & 21.4 & 19.0 & 561 & 565 & 551 \\
July & 22.0 & 22.3 & 21.7 & 21.6 & 525 & 571 & 555 \\
August & 21.1 & 19.3 & 20.6 & 20.7 & 477 & 440 & 440 \\
September & 16.8 & 16.5 & 15.0 & 15.1 & 325 & 323 & 329 \\
October & 9.7 & 8.7 & 4.4 & 7.5 & 188 & 230 & 186 \\
\hline
\end{tabular}

${ }^{\dagger}$ No historical data available. $\ddagger$ Historical data represent a 30-year average from 1981 to 2010 [35]. § Total incident solar radiation flux density is measured in Watts $\mathrm{m}^{-2}$ at approximately $2 \mathrm{~m}$ above the soil surface with a pyranometer. The solar radiation energy units reported are Langleys (Ly) per day or $\mathrm{MJ} \mathrm{m}^{-2} \mathrm{day}^{-1}$. One $\mathrm{Ly}=1$ calorie $\mathrm{cm}^{-2}$.

Table 5. Analysis of variance and mean squares for cover crops (CC) and cultivars (Cul) across four environments (Env) in Fargo, ND, USA, 2016-2018

\begin{tabular}{|c|c|c|c|c|c|c|c|c|}
\hline SOV & df & $\begin{array}{l}\text { Wheat } \\
\text { Canopy } \\
\text { Coverage }\end{array}$ & $\begin{array}{l}\text { Soybean } \\
\text { Yield }\end{array}$ & Wheat Yield & $\mathbf{d f}^{+}$ & $\begin{array}{c}\text { Fall Canopy } \\
\text { Coverage }\end{array}$ & $\begin{array}{c}\text { Spring } \\
\text { Canopy } \\
\text { Coverage }\end{array}$ & $\begin{array}{c}\text { Spring CC } \\
\text { Biomass }\end{array}$ \\
\hline Env & 3 & 2.232 & 505990 & 21717067 & 3 & 0.5369 & 0.3736 & 1556563 \\
\hline Rep (Env) & 12 & 0.007 & 542972 & 853373 & 12 & 0.0597 & 0.0177 & 81544 \\
\hline Cul & 3 & 0.001 & 1614987 * & 95644 & 3 & $0.0239 *$ & 0.0035 & 35460 \\
\hline Env $\times$ Cul & 9 & 0.003 & 117854 & 67174 & 9 & 0.0121 & 0.0019 & 23671 \\
\hline $\mathrm{CC}$ & 4 & 0.273 * & 70538 & 1102703 * & 3 & 0.1413 * & 0.3046 * & 973545 \\
\hline Env $\times C C$ & 12 & 0.096 & 41174 & 1045313 & 9 & 0.0223 & 0.0717 & 267847 \\
\hline $\mathrm{Cul} \times \mathrm{CC}$ & 12 & 0.001 & 23022 & 52859 & 9 & 0.0039 & 0.0018 & 20706 \\
\hline $\mathrm{Env} \times \mathrm{Cul} \times \mathrm{CC}$ & 36 & 0.002 & 32093 & 95382 & 27 & 0.0026 & 0.0018 & 17095 \\
\hline Error & 228 & 0.003 & 26699 & 105005 & 180 & 0.0060 & 0.0026 & 14737 \\
\hline
\end{tabular}

* Significant at the 0.05 probability level. ${ }^{\dagger}$ Cover crop check plots removed from data.

Cover crop fall canopy coverage percentages followed expected outcomes with the greatest value associated with the 0.4 soybean maturity and lowest with 0.9 (Table 6). These differences were expected due to 0.4 maturity soybean cultivar entering plant senescence much quicker than the 0.9 cultivar, allowing for greater light penetration and decreased competition of the soybean with the interseeded cover crops. Despite increased canopy coverage percentages from the cover crops in the earlier maturity soybean group, cover crop biomass differences were not observed due to cultivar maturity differences (Table 6).

Table 6. Mean fall and spring canopy coverage and cover crop biomass for four soybean cultivars across four environments in Fargo, ND, USA, from 2016, 2017, and 2018.

\begin{tabular}{ccccc}
\hline Cultivar & Fall Canopy Coverage & Spring Canopy Coverage & Cover Crop Biomass \\
\hline \multicolumn{7}{c}{$\%$} & \% & kg ha $^{-\mathbf{1}}$ \\
\hline AG0434 & 12.6 & $\mathrm{a}^{+}$ & 10.7 & 234 \\
AG0536 & 11.5 & $\mathrm{a}$ & 10.3 & 193 \\
AG0835 & 10.0 & $\mathrm{a}$ & 9.4 & 216 \\
AG0934 & 8.2 & $\mathrm{~b}$ & 9.1 & 182 \\
LSD 0.05 & & & $\mathrm{ns}$ & $\mathrm{ns}$
\end{tabular}

${ }^{\dagger}$ Within a column, mean followed by a different letter is significantly different at $p \leq 0.05$. ns $=$ not significant.

If seeding the cover crop earlier increases soil coverage, early-maturing soybean cultivars may have the advantage over late-maturing cultivars. However, cultivars with later relative maturities had higher soybean yield (Table 7), as was also found by [43]. 
Table 7. Mean soybean yield, wheat yield, and wheat canopy coverage readings for four soybean cultivars averaged across four environments in Fargo, ND, USA, from 2016, 2017, and 2018.

\begin{tabular}{|c|c|c|c|c|}
\hline \multirow[t]{2}{*}{ Cultivar } & \multicolumn{2}{|c|}{ Soybean Yield } & Wheat Yield & Wheat Canopy Coverage \\
\hline & \multicolumn{3}{|c|}{$\mathrm{kg} \mathrm{ha}^{-1}$} & $\%$ \\
\hline AG0434 & 2037 & $\mathrm{~d}^{+}$ & 2715 & 47.8 \\
\hline AG0536 & 2154 & $\mathrm{c}$ & 2631 & 48.0 \\
\hline AG0835 & 2270 & $\mathrm{~b}$ & 2665 & 47.8 \\
\hline AG0934 & 2365 & a & 2677 & 48.4 \\
\hline LSD 0.05 & & & ns & ns \\
\hline
\end{tabular}

${ }^{\dagger}$ Within a column, mean followed by a different letter are significantly different at $\mathrm{p} \leq 0.05$. ns = not significant.

The greatest yield difference averaged across all environments was shown between the AG0434 (2340 kg ha-1) and AG0934 (2675 kg ha $\left.{ }^{-1}\right)$, which equals to a monetary difference of $\$ 17.37 \mathrm{ha}^{-1}$, using a $\$ 0.294 \mathrm{~kg}^{-1}$ soybean price. This negative return for the benefit of reduced competition of the soybean plant (for AG0434) needs to be considered by agricultural producers to determine the best economic return for an interseeded-cover crop system. This research did not analyze the benefit of the increased biomass for potential reduced fertilizer application in future crops, herbicide cost reduction, and potential longterm soil health benefits. Several studies have been conducted about economic returns on cover crops [44-46], yet further research is suggested to improve grower decision making of maximum cover crop economic benefit to improve sustainability of interseeding cover crops into soybean.

Further research needs to be conducted to show the economic return resulting from the additional cover crop growth achieved by interseeding into an early-maturing soybean cultivar compared with the lower yield and monetary loss associated with not planting a later maturing cultivar. The wheat grain yield was not influenced by the soybean maturity of the cultivar (Table 7).

\subsubsection{Cover Crops by Seeding Rate}

Nearly all cover crop treatments metrics were significantly different when comparing winter rye and winter camelina (Table 8 ). Rye had higher cover percent and biomass. No significant differences were found between seeding rate treatments within rye or camelina, although all $100 \%$ seeding rate treatments produced larger values. The lower seeding rates would allow for reduced cover crop seed expense. Despite no differences between seeding rates in this study, several studies have suggested positive results for $100 \%$ seeding rate treatments [47].

Table 8. Mean fall and spring canopy coverage and cover crop biomass for cover crops across four environments in Fargo, ND, USA, from 2016, 2017, and 2018.

\begin{tabular}{|c|c|c|c|c|c|c|}
\hline \multirow[t]{2}{*}{ Cultivar } & \multicolumn{2}{|c|}{ Fall Canopy Coverage } & \multicolumn{2}{|c|}{ Spring Canopy Coverage } & \multicolumn{2}{|c|}{ Spring Cover Crop Biomass } \\
\hline & \multicolumn{4}{|c|}{$\%$} & \multicolumn{2}{|c|}{$\mathrm{kg} \mathrm{ha}^{-1}$} \\
\hline Camelina100 & 7.0 & $b^{+}$ & 4.3 & $b$ & 103 & $\mathrm{~b}$ \\
\hline Camelina75 & 6.4 & $\mathrm{~b}$ & 3.7 & $\mathrm{~b}$ & 97 & $\mathrm{~b}$ \\
\hline Rye100 & 16.2 & $\mathrm{a}$ & 16.1 & a & 321 & a \\
\hline Rye75 & 12.8 & $\mathrm{a}$ & 15.5 & a & 304 & a \\
\hline
\end{tabular}

${ }^{\dagger}$ Within a column, mean followed by a different letter is significantly different at $p \leq 0.05$.

Rye treatments coverage percent and biomass values observed upwards of three times those of the winter camelina values (Table 8). These values were consistent across all environments and similar to trends found in other research $[24,25]$. No economical or soil nutrient analysis was done in this study to show the economic impact of these differences, yet based on this study's data, rye was superior compared with camelina.

Soybean yield was not different for soybean interseeded with camelina or rye compared with soybean without a cover crop (Table 9). For the HRSW growing seasons of 
2017 and 2018, the termination of the cover crops was conducted using an application of Roundup WeatherMAX applied the same day as HRSW planting. Ten days after termination, winter camelina was visually eliminated with limited competition with HRSW. Winter rye took 30 to $45 \mathrm{~d}$ to become eliminated, and by this time, the HRSW had nearly $35 \%$ canopy coverage and was beginning to tiller.

Table 9. Mean soybean (2016-2017) and wheat yield (2017-2018) and wheat canopy coverage for five cover crops across four environments in Fargo, ND, USA.

\begin{tabular}{cccccc}
\hline Cultivar & Soybean Yield & \multicolumn{2}{c}{ Wheat Yield } & \multicolumn{2}{c}{ Wheat Canopy Coverage } \\
\hline & \multicolumn{3}{c}{ kg ha $^{-1}$} & \multicolumn{2}{c}{$\%$} \\
\hline Camelina100 & 2208 & 2718 & $\mathrm{a}^{+}$ & 52.0 & $\mathrm{a}$ \\
Camelina75 & 2193 & 2767 & $\mathrm{a}$ & 51.7 & $\mathrm{a}$ \\
Rye100 & 2197 & 2507 & $\mathrm{~b}$ & 40.1 & $\mathrm{~b}$ \\
Rye75 & 2175 & 2562 & $\mathrm{~b}$ & 41.9 & $\mathrm{~b}$ \\
Check & 2262 & 2808 & $\mathrm{a}$ & 51.9 & $\mathrm{a}$ \\
LSD 0.05 & $\mathrm{ns}$ & & & \\
\hline
\end{tabular}

$\overline{{ }^{\dagger} \text { Within a column, mean followed by a different letter are significantly different at } p \leq 0.05 . \mathrm{ns}=\text { not significant. }}$

An advantage of chemical elimination of the cover crop is protection to the soil from wind erosion and excess sunlight resulting in preventing moisture loss or crusting, compared with tillage. The wheat after cereal rye plots were significantly inhibited in growth (Table 9) and vigor as expected, which is constant with previous research [48].

This wheat yield difference after rye (Table 9) was caused by the substantial biomass growth produced by cereal rye, $313 \mathrm{~kg} \mathrm{ha}^{-1}$ average of both seeding rates, as compared with biomass of winter camelina at $100 \mathrm{~kg} \mathrm{ha}^{-1}$, average of both seeding rates, respectively (Table 8). These biomass differences compounded by late termination of cover crops, canopy coverage differences, and slower herbicide (glyphosate) action in rye resulted in the significant differences of the wheat cover percentage and yield (Table 9).

The substantial wheat biomass growth inhibition due to the late termination of the cover crops was exacerbated by the no-till tillage system as crop residue was high. Since the rye showed canopy cover percentages averaging above $38 \%$ at termination, germinating HRSW plants were covered by the dying cereal rye plants. This difference between rye and camelina or check plots was easily observed, with the cereal rye plots expressing stunting, chlorosis, and poor vigor.

The economic loss using wheat yield data between check plots (2808 $\mathrm{kg} \mathrm{ha}^{-1}$ ) and rye plots (2535 $\mathrm{kg} \mathrm{ha}^{-1}$ ) (Table 9) was about $\$ 60.33 \mathrm{ha}{ }^{-1}$ using a price of $\$ 0.22 \mathrm{~kg}^{-1}$ for wheat. With this amount of economic loss, planting rye before growing HRSW is not recommended when rye is chemically terminated at the same time as wheat planting. Further research is needed to investigate if other termination timings will have different results and evaluate the economic cost or benefits.

Producers are interested in including cover crops in their farming systems to increase soil protection and soil health benefits. Additional research will be needed to evaluate the long-term benefits of cover crops after soybean.

\section{Conclusions}

Earlier maturing soybean cultivars produced increased cover crop growth resulting in increased canopy coverage. However, the opportunity cost of planting an earlier maturing cultivar may be larger due to reduction of soybean yield compared with the later maturing cultivar. The early maturing cultivar with 0.4 maturity had higher cover crop soil cover percent later in the fall and early in the spring, with $53.7 \%$ more canopy coverage in the fall compared with the 0.9 maturity cultivar when cover crops were planted at the R7 growth stage of the early maturing cultivar.

Cover crop seeding rates did not increase cover crop biomass production. Interseeded cover crops into different cultivars at the R7 stage of the early maturity cultivars did not 
reduce soybean yield compared with the check plot, which is consistent with previous research. Growing HRSW after interseeded cereal rye into soybean resulted in reduced yields compared with winter camelina and the check plots. This was expected, as the HRSW cover percentage after rye was significantly lower compared with camelina and check plots, and the visual stress observed during the summer months was obvious. Further research needs to be conducted to show the economic return resulting from the cover crop grow after soybean.

Author Contributions: K.L.J.: Conceptualization, formal analysis, investigation, methodology, writing—original draft, writing—review and editing. H.J.K.: Conceptualization, investigation, supervision, writing—review and editing. D.P.S.: Writing—review and editing. M.T.B.: Formal analysis, funding acquisition, investigation, project administration, resources, writing-review and editing. All authors have read and agreed to the published version of the manuscript.

Funding: This project was funded by USDA-NIFA, Award no. 2016-69004-24784

Acknowledgments: The authors would like to thank Chad Deplazes and Darin Eisinger for their technical assistance.

Conflicts of Interest: The authors declare no conflict of interest.

\section{References}

1. Dickey, E.C.; Shelton, D.P.; Jasa, P.J.; Peterson, T.R. Soil erosion form tillage systems used in soybean and corn residues. Trans. ASAE 1985, 28, 1124-1130. [CrossRef]

2. Franzen, D.; Goos, R.J.; Kandel, H.; Augustin, C.; Buetow, R.; Teboh, J.; Forster, S.; Endres, G. Soybean Soil Fertility; NDSU Ext. Serv. SF1164 (Revised Nov. 2019); North Dakota Agric. Exp. Station: Fargo, ND, USA, 2019.

3. NRCS (Natural Resources Conservation Service). Cover Crop Termination Guidelines Version 4. USDA Risk Management Agency. 2021. Available online: https:/ / www.rma.usda.gov/Topics/Cover-Crops (accessed on 16 January 2021).

4. Robertson, G.P.; Gross, K.L.; Hamilton, S.K.; Landis, D.A.; Schmidt, T.M.; Snapp, S.S.; Swinton, S.M. Farming for ecosystem services: An ecological approach to production agriculture. In The Ecology of Agricultural Landscapes: Long-Term Research on the Path to Sustainability; Hamilton, S.K., Doll, J.E., Robertson, G.P., Eds.; Oxford Univ. Press: New York, NY, USA, 2015 ; pp. $33-53$.

5. Delgado, J.A.; Gantzer, C.J. The 4Rs for cover crops and other advances in cover crop management for environmental quality. J. Soil Water Conserv. 2015, 70, 142A-145A. [CrossRef]

6. Garbeva, P.; van Veen, J.A.; van Elsas, J.D. Microbial diversity in soil: Selection of microbial populations by plant and soil type and implications for disease suppressiveness. Ann. Rev. Phytopathol. 2004, 42, 243-270. [CrossRef] [PubMed]

7. Gasch, C.; DeJong-Hughes, J. Soil Organic Matter Does Matter; SF1942; North Dakota State Univ. Ext. Pub.: Fargo, ND, USA, 2019.

8. Lu, Y.C.; Watkins, K.B.; Teasdale, J.R.; Abdul-Baki, A.A. Cover crops in sustainable food production. Food Rev. Intern. 2000, 16, 121-157. [CrossRef]

9. O’Brien, P.L.; Hatfield, J.L.; Dold, C.; Kistner-Thomas, E.J.; Wacha, K.M. Cropping pattern changes diminish agroecosystem services in North and South Dakota, USA. Agron. J. 2020, 112, 1-24. [CrossRef]

10. Syswerda, S.P.; Robertson, G.P. Ecosystem services along a management gradient in Michigan (USA) cropping systems. Agric. Ecosyst. Environ. 2014, 189, 28-35. [CrossRef]

11. Schipanski, M.E.; Barbercheck, M.; Douglas, M.R.; Finney, D.M.; Haider, K.; Kayne, J.P.; Kemaian, A.R.; Mortensen, D.A.; Ryan, M.R.; Tooker, J.; et al. A framework for evaluating ecosystem services provided by cover crops in agroecosystems. Agric. Syst. 2014, 125, 12-22. [CrossRef]

12. Berti, M.; Gesch, R.; Eynck, C.; Anderson, J.; Cermak, S. Camelina uses, genetics, genomics, production, and management. Ind. Crops Prod. 2016, 94, 690-710. [CrossRef]

13. Anderson, J.V.; Horvath, D.P.; Doğramac1, M.; Dorn, K.M.; Chao, W.S.; Watkin, E.; Marks, M.D.; Gesch, R. Expression of FLOWERING LOCUS C and a frame shift mutation of this gene on chromosome 20 differentiate a summer- and winter-annual biotype of Camelina sativa. Plant Direct 2018, 2, 1-14. [CrossRef]

14. Wittenberg, A.; Anderson, J.V.; Berti, M.T. Winter and summer annual biotypes of camelina have different morphology and seed characteristics. Ind. Crops Prod. 2019, 135, 230-237. [CrossRef]

15. Gesch, R.W.; Archer, D.; Berti, M.T. Dual cropping winter camelina with soybean in the northern Corn Belt. Agron. J. 2014, 106, 1735-1745. [CrossRef]

16. Gesch, R.; Cermak, S. Sowing date and tillage effects on fall-planted camelina in the northern Corn Belt. Agron. J. 2011, 103, 980-987. [CrossRef]

17. Berti, M.; Samarappuli, D.; Johnson, B.L.; Gesch, R.W. Integrating winter camelina into maize and soybean cropping systems. Ind. Crops Prod. 2017, 107, 595-601. [CrossRef]

18. Snapp, S.; Swinton, S.; Labarta, R.; Mutch, D.; Black, J.; Leep, R.; Nyiraneza, J.; O’Neil, K. Evaluating cover crops for benefits, costs and performance within cropping system niches. Agron. J. 2005, 97, 322-332. 
19. Wilson, M.L.; Baker, J.M.; Allan, D.L. Factors affecting successful establishment of aerially seeded winter rye. J. Environ. Qual. 2013, 33, 1010. [CrossRef]

20. Crowley, K.A.; Van Es, H.M.; Gomex, M.I.; Ryan, M.R. Trade-offs in cereal rye management strategies prior to organically managed soybean. Agron. J. 2018, 110, 1492-1504. [CrossRef]

21. Kladivko, E.; Kaspar, T.; Jaynes, D.; Malone, R.; Singer, J.; Morin, X.; Searchinger, T. Cover crops in the upper Midwest USA: Potential adoption and reduction of nitrate leaching in the Mississippi River Basin. J. Soil Water Conserv. 2014, 69, $279-291$. [CrossRef]

22. SARE (Sustainable Agriculture Research and Education). Managing Cover Crops Profitably, 3rd ed.; Handbook Series 9; SARE: College Park, MD, USA, 2012; pp. 98-105.

23. Weil, R.; Kremen, A. Thinking across and beyond disciplines to make cover crops pay. J. Sci. Food Agric. 2007, 87, 551-557. [CrossRef]

24. Mohammed, Y.A.; Matthees, H.L.; Gesch, R.W.; Patel, S.; Forcella, F.; Aasand, K.; Steffl, N.; Johnson, B.L.; Wells, M.S.; Lenssen, A.W. Establishing winter annual cover crops by interseeding into maize and soybean. Agron. J. 2020, 1-14. [CrossRef]

25. Peterson, A.T.; Berti, M.T.; Samarappuli, D. Intersowing cover crops into standing soybean in the US Upper Midwest. Agronomy 2019, 9, 264. [CrossRef]

26. Midwest Cover Crops Council. Integrating Cover Crops in Soybean Rotations: Challenges and Recommendations for the North Central Region. 2015. Available online: http://mccc.msu.edu/wp-content/uploads/2016/10/ALL_2015_Integrating-covercrops-in-soybean-rotations.pdf (accessed on 16 January 2021).

27. Uchino, H.; Iwama, K.; Jitsuyama, Y.; Ichiyama, K.; Sugiura, E.; Yudate, T.; Nakamura, S.; Gopal, J. Effect of interseeding cover crops and fertilization on weed suppression under an organic and rotational cropping system: 1 . Stability of weed suppression over years and main crops of potato, maize and soybean. Field Crops Res. 2012, 127, 9-16. [CrossRef]

28. Masilionyte, L.; Maiksteniene, S.; Kriauciuniene, Z.; Jablonskyte-Rasce, D.; Zou, L.; Sarauskis, E. Effect of cover crops in smothering weeds and volunteer plants in alternative farming systems. Crop Prot. 2017, 91, 74-81. [CrossRef]

29. Fisher, K.A.; Momen, B.; Kratochvil, R.J. Is broadcasting seed an effective winter cover crop planting method? Agron. J. 2011, 103, 472-478. [CrossRef]

30. Parkin, T.B.; Kaspar, T.C.; Cambardella, C.A. Small grain cover crops to manage nitrogen in the Midwest. In Proceedings of the Cover Crops, Soil Quality, and Ecosystems Conference, Sacramento, CA, USA, 12-14 March 1997.

31. Eckert, D.J. Chemical attributes of soils subjected to no-till cropping with rye cover crops. Soil Sci. Soc. Am. J. 1991, 55, 405-409. [CrossRef]

32. Hively, W.D.; Cox, W.J. Interseeding cover crops into soybean and subsequent corn yields. Agron. J. 2001, 93, 308-313. [CrossRef]

33. Koehler-Cole, K.; Elmore, R.W. Seeding rates and productivity of broadcast interseeded cover crops. Agronomy 2020, 10, 1723. [CrossRef]

34. USDA (United States Department of Agriculture). Web Soil Survey. 2021. Available online: https://websoilsurvey.sc.egov.usda gov/App/HomePage.htm (accessed on 16 January 2021).

35. NDAWN. North Dakota Agricultural Weather Network; North Dakota State Univ.: Fargo, ND, USA, 2020; Available online: http:/ / ndawn.ndsu.nodak.edu (accessed on 16 January 2021).

36. Helms, T.C.; Scot, R.A.; Schapaugh, W.T.; Goos, R.J.; Franzen, D.W.; Shlegel, A.J. Soybean iron-deficiency chlorosis tolerance and yield decrease on calcareous soils. Agron. J. 2010, 102, 492-498. [CrossRef]

37. Kandel, H.; Endres, G. Soybean Production Field Guide; A1172; North Dakota State Univ. Ext. Pub.: Fargo, ND, USA, 2019.

38. Knodel, J.; Beauzay, P.; Boetel, M.; Prochaska, T.J.; Lubenow, L. North Dakota Field Crop Insect Management Guide; NDSU Ext. E1143-20; North Dakota Agric. Exp. Station: Fargo, ND, USA, 2020.

39. Patrignani, A.; Ochsner, T.E. Canopeo: A powerful new tool for measuring fractional green canopy cover. Agron. J. 2015, 107, 2312-2320. [CrossRef]

40. Fehr, W.R.; Caviness, C.E.; Burmood, D.T.; Pennington, J.S. Stage of development descriptions for soybeans, Glycine max (L.) Merrill. Crop Sci. 1971, 11, 929-931. [CrossRef]

41. Zadoks, J.C.; Chang, T.T.; Konzak, C.F. A decimal code for the growth stages of cereals. Weed Res. 1974, 14, 415-421. [CrossRef]

42. SAS Institute. SAS User's Guide; Statistics; SAS Institute: Cary, NC, USA, 2020.

43. Egli, D.B. Cultivar maturity and potential yield of soybean. Field Crops Res. 1993, 32, 147-158. [CrossRef]

44. Plastina, A.; Liu, F.; Sawadgo, W.; Miguez, F.; Carlson, F. Partial budgets for cover crops in Midwest row crop farming. J. ASFMRA 2018, 90-106. [CrossRef]

45. Bergtold, J.; Ramsey, S.; Maddy, L.; Williams, J. A review of economic considerations for cover crops as a conservation practice. Renew. Agric. Food Syst. 2019, 34, 62-76. [CrossRef]

46. Myers, R.; Weber, A.; Tellatin, S. Cover Crop Economics: Opportunities to Improve Your Bottom Line in Row Crops. SARE Technical Bulletin. 2019. Available online: https://extension.umd.edu/sites/extension.umd.edu/files/_docs/SARE\%20Cover\% 20Crop\%20Economics\%202019.pdf (accessed on 16 January 2021).

47. Gesch, R.W.; Matthees, H.L.; Alvarez, A.L.; Gardner, R.D. Winter camelina: Crop growth, seed yield, and quality response to cultivar and seeding rate. Crop Sci. 2018. [CrossRef]

48. Nielsen, D.C.; Lyon, D.J.; Higgins, R.K.; Hergert, G.W.; Holman, J.D.; Vigil, M.F. Cover crop effect on subsequent wheat yield in the central Great Plains. Agron. J. 2016, 108, 243-256. [CrossRef] 